\title{
PKM Penyuluhan Akibat Hukum Perkawinan di Bawah Tangan (Sirri) bagi Santriwati Pondok Pesantren Al-Mashduqiah Probolinggo
}

\author{
Fatimah Al Zahra' ${ }^{1}$, Muflahatul Hasanah², Nur Hasanah'3 ${ }^{3}$ Ika Wijayanti ${ }^{4}$, \\ Fitria Wulandari ${ }^{5}$, Zaybi Tsabti Barillah' ${ }^{6}$, Muinatul Mufidah ${ }^{7}$ \\ Universitas Nurul Jadid, Paiton ${ }^{123}$ \\ iza.fhub@gmail.com¹, muflah.cahaya@gmail.com², nhs.ana99@gmail.com³, \\ kingzaybi24@gmail.com ${ }^{4}$, fitriawulandari448@gmail.com ${ }^{5}$, \\ wijaikayantii@gmail.com ${ }^{6}$, muinatulmufidah@gmail.com
}

\begin{tabular}{ll}
\hline Submission: 30/09/2021 Received: 31/12/2021 Published: 31/12/2021 \\
\hline $\begin{array}{l}\text { Keywords: } \\
\text { Keywords: }\end{array}$ & underact. Various laws and regulations related to the prohibition of \\
counseling, & widely known by the public, especially those in Islamic boarding \\
legal & schools who are not legal. The legal consequences arising from \\
consequences, & underhanded marriages (sirri) not only have a negative impact on the \\
underhanded & wife, but also for children born from underhanded marriages (sirri). \\
marriage (sirri) & Therefore, it is necessary to conduct socialization and legal \\
& counseling to the community about the negative impact on wives and \\
& children of underhanded marriages (sirri). The purpose of this activity \\
& is to educate and provide legal counseling for senior students at the \\
& Al-Mashduqiah Islamic Boarding School located in Patokan Village, \\
& Kraksan District, Probolinggo Regency so that awareness and \\
& changes in perspective that have been wrong so far consider \\
& underhanded marriage (sirri) as something. legal in the eyes of the \\
& law. In general, the method used is counseling and interactive \\
& discussion, using various equipment and materials to facilitate the \\
delivery and acceptance of extension and socialization materials. The \\
activity of this program is to explain the legal consequences that will \\
occur from underhanded marriages (sirri), so that they can increase \\
the legal understanding of senior female students and become a \\
material for consideration before marriage in the future.
\end{tabular}

Katakunci:

Kata Kunci: penyuluhan, akibat hukum, perkawinan di bawah tangan (sirri)

\begin{abstract}
Abstrak. Berbagai peraturan perundang-undangan yang terkait dengan larangan perkawinan di bawah tangan (sirri) telah lama diundangkan, namun tidak banyak diketahui oleh masyarakat, khususnya masyarakat di lingkungan pesantren yang menganggap praktik perkawinan di bawah tangan (sirri) itu sah karena tidak dilarang dalam syariat Islam. Akibat hukum yang timbul dari perkawinan di bawah tangan (sirri) tidak hanya berdampak negatif bagi istri, namun juga bagi anak yang dilahirkan dari perkawinan di bawah tangan (sirri). Oleh karena itu, perlu dilakukan sosialisasi dan penyuluhan hukum kepada masyarakat tentang dampak negatif bagi istri dan anak dari perkawinan di bawah tangan (sirri). Tujuan kegiatan ini adalah mengedukasi dan memberikan penyuluhan hukum bagi santriwati senior Pondok Pesantren Al-Mashduqiah yang
\end{abstract}


terletak di Kelurahan Patokan, Kecamatan Kraksaan, Kabupaten Probolinggo agar muncul kesadaran dan perubahan cara pandang yang selama ini salah karena menganggap perkawinan di bawah tangan (sirri) sebagai sesuatu yang sah di mata hukum. Secara umum, metode yang digunakan adalah penyuluhan dan diskusi interaktif, dengan menggunakan berbagai perlalatan dan bahan untuk memudahkan dalam penyampaian dan penerimaan materi penyuluhan dan sosialisasi. Kegiatan dari program ini adalah menjelaskan akibat hukum yang akan terjadi dari perkawinan di bawah tangan (sirri), sehingga bisa menambah pemahaman hukum para santriwati senior dan menjadi bahan pertimbangan sebelum melakukan perkawinan di kemudian hari.

\section{Pendahuluan}

Keinginan untuk melangsungkan perkawinan merupakan fitrah setiap makhluk ciptaan Allah, dengan harapan agar dengan perkawinan tersebut, kehidupan di alam dunia ini bisa terus berkembang dan berlanjut dari suatu generasi ke generasi berikutnya. Perkawinan adalah tuntutan naluri yang berlaku pada semua makhluk-Nya, baik pada manusia, hewan maupun tumbuh-tumbuhan (Hadikusuma, 2010). Oleh karena manusia sebagai makhluk yang berakal, maka perkawinan bagi manusia menjadi suatu tradisi yang harus dilestarikan sebagai usaha untuk melanjutkan keturunan dan kelangsungan hidup. Jika manusia menggunakan akalnya dengan baik, maka akan dapat disimpulkan bahwa perkawinanlah satu-satunya cara untuk memperoleh keturunan.

Dalam masyarakat sederhana, budaya perkawinannya sempit dan bahkan tertutup, sedangkan dalam masyarakat berbentuk modern, budaya perkawinannya maju, luas, serta terbuka (Hadikusuma, 2010). Keluarga merupakan satuan sosial masyarakat terkecil yang sangat menentukan atau pilar utama dalam pembangunan masyarakat. (Prihatin, 2009). Manusia melangsungkan perkawinan dengan berbagai ketentuan yang sakral, hal ini berbeda dengan binatang yang melakukan perkawinan dengan bebas sekehendak hawa nafsunya. Bagi binatang, perkawinan semata-mata untuk memenuhi keperluan birahi dan kepuasan nafsu. Sedangkan bagi manusia, perkawinan diatur oleh berbagai etika dan pengaturan lain yang menjunjung tinggi nilai-nilai kemanusiaan yang beradab dan berakhlak. Oleh karena itu, manusia harus mengikuti tata cara perkawinan berdasarkan norma hukum dan norma agama yang diterapkan di Indonesia. 
Perkawinan bertujuan untuk melanjutkan sejarah manusia, karena keturunan yang baik harus dilalui dengan perkawinan yang sah menurut norma yang berlaku. Jika perkawinan dilakukan tanpa aturan, maka sejarah peradaban manusia tentu tidak ada beda dengan binatang (Muthiah, 2017). Adapun mengenai norma yang berlaku untuk perkawinan adalah berdasarkan norma hukum dan norma agama, norma hukum mengacu pada UndangUndang Nomor 1 Tahun 1974 tentang Perkawinan jo. Undang-undang (UU) Nomor 16 Tahun 2019 tentang Perubahan atas Undang-undang Nomor 1 Tahun 1974 tentang Perkawinan, sedangkan norma agama mengacu pada KHI (Kompilasi Hukum Islam). Setelah berlakunya Undang-Undang Nomor 1 Tahun 1974 tentang Perkawinan, khususnya bagi umat Islam, pernikahan yang dilakukan oleh masyarakat haruslah dicatat oleh Kantor Urusan Agama (KUA).

Akad nikah yang dilaksanakan oleh pihak keluarga pengantin pria bersama pengantin wanita tanpa dihadiri oleh pejabat KUA banyak terjadi di kalangan anggota masyarakat yang ingin berpoligami atau yang ingin beristeri lebih dari satu secara diam-diam agar tidak diketahui oleh pihak isteri dan atau anakanak dari si suami. Sebab acapkali seorang laki-lelaki merahasiakan dan menutup-nutupi dari isteri resminya dan menempatkan budak wanita itu dirumah lain. (Hasan, 2013) Pernikahan ini bertentangan dengan UndangUndang Nomor 1 Tahun 1974 tentang Perkawinan yang mengharuskan seorang suami apabila ingin beristeri lebih dari satu, harus mendapat persetujuan dari isterinya atau isteri-isterinya dan mendapat izin dari Pengadilan Agama. Perkawinan secara diam-diam seperti ini di dalam masyarakat seringkali disebut dengan perkawinan sirri.

Latar belakang terjadinya perkawinan sirri ini disebabkan pihak pengantin pria dan wanita tersebut ingin menghindar dari Undang-Undang Nomor 1 Tahun 1974 tentang Perkawinan. Dalam Pasal 3 ayat (1) Undang-Undang Nomor 1 Tahun 1974 tentang Perkawinan dinyatakan bahwa: "Pada asasnya dalam suatu perkawinan, seorang pria hanya boleh mempunyai seorang isteri. Seorang wanita hanya boleh mempunyai seorang suami". Sejatinya Undang-Undang Nomor 1 Tahun 1974 menganut asas monogami. Dalam Pasal 3 ayat (2) Undang-Undang Nomor 1 Tahun 1974 dinyatakan pula bahwa: "Pengadilan dapat memberi izin kepada seorang suami untuk beristeri lebih dari seorang apabila dikehendaki oleh pihak-pihak yang bersangkutan." Hal 
ini berarti bahwa suami diperbolehkan beristeri lebih dari satu orang apabila hal itu disetujui oleh isterinya. Aturan ini ditegaskan dalam Pasal 4 Ayat (1) dan (2) Undang-Undang Nomor 1 Tahun 1974, yang berbunyi:

(1) "Dalam hal seorang suami akan beristeri lebih dari seorang, maka ia wajib mengajukan permohonan kepada Pengadilan di daerah tempat tinggalnya."

(2) "Pengadilan hanya memberikan izin kepada suami yang akan beristeri lebih dari seorang (berpoligami) apabila, Isteri tidak dapat menjalankan kewajibannya sebagai isteri, isteri mendapat cacat badan atau penyakit yang tidak dapat disembuhkan, isteri tidak dapat melahirkan keturunan."

Syarat-syarat yang harus dipenuhi terlebih dahulu agar permohonan menikah lagi dari seorang suami dapat disetujui oleh Pengadilan diatur secara tegas dalam Pasal 5 ayat (1) butir a, butir b, dan butir c, antara lain: adanya persetujuan dari istri atau istri-istrinya, adanya kepastian bahwa suami dapat menjamin keperluan hidup isteri-isteri dan anak-anak mereka, dan adanya kepastianbahwa suami mampu berlaku adil terhadap isteri-isteri dan anakanak mereka. Adanya persyaratan seperti di dalam Pasal 5 ayat (1) butir b dan butir c dipandang masyarakat sebagai persyaratan yang memang seharusnya ada dan logis. Akan tetapi persyaratan yang ada di dalam Pasal 5 ayat (1) butir a yang mengharuskan seorang suami untuk mendapatkan persetujuan dari isterinya dianggap berlebihan karena dirasa sangat sulit untuk mendapatkan izin untuk berpoligami dari istri yang sebelumnya.

Kewenangan untuk memeriksa persyaratan perkawinan terletak di tangan Pegawai Pencatat dari KUA, hal ini diatur dalam Pasal 6 ayat (1) Peraturan Pemerintah Nomor 9 Tahun 1975 Tentang Pelaksanaan Undang-undang Nomor 1 Tahun 1974 Tentang Perkawinan yang menyebutkan bahwa "Pegawai Pencatat yang menerima pemberitahuan kehendak melangsungkan perkawinan, meneliti apakah syarat-syarat perkawinan telah dipenuhi dan apakah tidak terdapat halangan perkawinan menurut Undang undang". Namun dalam kenyataannya yang terjadi di lapangan, saat persyaratan perkawinan tersebut tidak terpenuhi sehingga seseorang terhalang oleh syarat perkawinan, banyak yang nekad untuk terus melangsungkan perkawinan secara tidak tercatat atau perkawinan sirri. Memang sangat jarang ditemukan isteri yang dengan sukarela memberikan izin atau persetujuan untuk suaminya menikah lagi atau berpoligami, meskipun 
terdapat syarat-syarat sebagaimana yang telah dijabarkan diatas. Oleh karena itu, suami yang ingin sekali mempunyai keturunan, atau yang isterinya menderita cacat fisik dan tidak dapat melaksanakan kewajibannya kepada suami, menempuh cara menikah dengan cara kawin sirri. Ada pula suami yang ingin menikah lagi karena merasa tidak cukup puas atau bosan dengan isterinya, akhirnya terpaksa menempuh cara kawin sirri.

Halangan dalam perkawinan sebagai akibat dari tidak terpenuhinya persyaratan yang ditentukan tidak hanya terjadi karena faktor izin dari isteri, namun juga terjadi pada seorang yang belum pernah menikah, baik laki-laki maupun wanita. Hal ini bisa terjadi karena ada persyaratan yang tidak terpenuhi oleh kedua belah pihak, antara lain: usia belum mencukupi dan terjadi hamil di luar nikah. Kurangnya batasan usia inilah yang banyak menyebabkan terjadinya praktik perkawinan sirri yang dilakukan oleh masyarakat Kabupaten Probolinggo. Pada tahun 2018, angka perkawinan dini di Kabupaten Probolinggo ini menduduki peringkat ketiga tertinggi di Jawa Timur setelah Kabupaten Sampang dan Kabupaten Sumenep (https://www.wartabromo.com/2019/03/01/kabupaten-probolinggorangking-3-pernikahan-dini/, diakses pada 12 September 2021). Tingginya angka pernikahan dini di Kabupaten Probolinggo ini bisa terjadi karena faktor kultur atau budaya masyarakat setempat. Kondisi ini sungguh sangat memprihatinkan dan perlu segera dicarikan solusinya.

Perkawinan sirri dipandang sah dalam perspektif agama Islam apabila telah terpenuhi rukun dan syaratnya, akan tetapi akad nikah secara sirri ini dapat menimbulkan dampak dan akibat hukum yang merugikan isteri dan anak-anak yang dihasilkan dari perkawinan tersebut. Hal ini terjadi karena perkawinan sirri tidak dikenal dan tidak diakui dalam hukum Negara Indonesia, sehingga perkawinan tersebut tidak dapat memberikan perlindungan hukum bagi istri dan anak. Hak isteri dan anak dapat dilindungi oleh hukum selama dapat menunjukkan alat bukti otentik tentang terjadinya perkawinan yang berupa akta nikah. Akta nikah dikeluarkan oleh KUA hanya jika perkawinan tersebut dilaksanakan di hadapan pegawai pencatat. Hal ini sesuai dengan amanat Pasal 6 Kompilasi Hukum Islam yang menyatakan bahwa: "Setiap perkawinan harus dilangsungkan di hadapan dan di bawah pengawasan Pegawai Pencatat Nikah." 
Berdasarkan bunyi pasal 6 tersebut, maka dapat disimpulkan bahwa perkawinan sirri tidak memiliki kekuatan hukum karena perkawinannya tidak dicatat atau tidak dilangsungkan di hadapan pegawai pencatat. Perkawinan sirri bahkan dianggap sebagai suatu pelanggaran, sebagaimana terdapat dalam Pasal 45 Peraturan Pemerintah Nomor 9 Tahun 1975. Persoalan akan muncul ketika perkawinan yang telah sah menurut agama Islam, akan tetapi tidak dicatatkan pada lembaga pencatatan negara, biasanya akan timbul banyak masalah setelah perkawinan berlangsung. Dapat dikatakan bahwa perkawinan sirri memberikan kesenangan di depan, namun membawa petaka di belakang dan berdampak negatif karena hukumnya tidak terpenuhi (Haem, 2011). Perkawinan sirri sangat merugikan bagi isteri dan anak yang dihasilkan dari perkawinan tersebut.

Isteri yang dikawin secara sirri tidak dianggap sebagai isteri sah di mata hukum, sehingga dia tidak berhak atas nafkah dan warisan dari suami jika kelak meninggal dunia. Menurut Undang-Undang Perkawinan dan Kompilasi Hukum Islam, anak yang sah adalah anak yang dilahirkan dalam atau akibat perkawinan yang sah, meskipun anak tersebut lahir dari perkawinan wanita hamil yang usia kandungannya kurang dari 6 bulan lamanya sejak ia menikah resmi. Pasal 42 Undang-Undang Nomor 1 Tahun 1974 secara tegas menyebutkan bahwa "Anak yang sah adalah anak yang dilahirkan dalam atau akibat perkawinan yang sah." Selanjutnya Pasal 43 Undang-Undang Nomor 1 Tahun 1974 menyebutkan bahwa "Anak yang dilahirkan di luar perkawinan hanya mempunyai hubungan perdata dengan ibunya dan keluarga ibunya." Bukti sah suatu garis keturunan dapat ditunjukkan melalui akta kelahiran yang di dalamnya menyebutkan asal-usul nama orang tua si anak. Berkenaan dengan pembuktian asal-usul anak, ditur lebih lanjut dalam Pasal 55 Undang-Undang Nomor 1 Tahun 1974 yang menyebutkan bahwa:

1. Asal-usul seorang anak hanya dapat dibuktikan dengan akta kelahiran yang otentik, yang dikelurkan oleh pejabat yang berwenang;

2. Bila akta kelahiran tersebut dalam ayat (1) pasal ini tidak ada, maka pengadilan dapat, mengeluarkan penetapan tentang asal-usul seorang anak setelah diadakan pemeriksaan yang teliti berdasarkan bukti-bukti yang memenuhi syara; 
3. Atas dasar ketentuan pengadilan tersebut ayat (2) pasal ini, maka instansi pencatat kelahiran yang ada dalam daerah kerja hukum pengadilan yang bersangkutan mengeluarkan akta kelahiran bagi anak yang bersangkutan.

Secara hukum, anak yang lahir dari perkawinan siri tidak dapat mengurus akta kelahiran yang mencantumkan nama ayah dan ibunya, sehingga status anak tersebut dianggap sebagai anak luar nikah di akta kelahirannya, tidak tertulis nama ayah kandungnya dan hanya tertulis ibu kandungnya saja. Keterangan berupa status sebagai anak luar nikah dan tidak tercatatnya nama si ayah akan berpengaruh secara sosial dan psikologis bagi si anak dan ibunya. Seringkali ketidakjelasan status si anak di muka hukum, mengakibatkan hubungan antara ayah dan anak tidak kuat, sehingga bisa saja suatu waktu ayahnya menyangkal bahwa anak tersebut adalah anak kandungnya. Dari berbagai masalah yang diuraikan di atas, dapat diidentifikasi dua hal yang penting, yaitu:

a. Berbagai peraturan perundang-undangan yang terkait dengan larangan perkawinan di bawah tangan (sirri) dan akibat hukumnya belum sepenuhnya tersosialisasi dengan baik;

b. Kesadaran dan pengetahuan masyarakat tentang dampak negatif bagi istri dan anak dari perkawinan di bawah tangan (sirri) masih rendah.

\section{Metode}

Metode pelaksaan pengabdian ini mengunakan metode deskriptif yang bersifat kualitatif. Metode deskriptif sebagai suatu penelitian yang bertujuan untuk menggambarkan secara rinci sesuatu yang berlangsung pada saat kegiatan dilakukan dan memeriksa sebab-sebab dari suatu gejala tertentu (Soejono Soekanto dan Sri Mamuji, 2001). Pengabdian ini berlokasi di Pondok Pesantren Al-Mashduqiah, Kecamatan Kraksaan, Kabupaten Probolinggo. Berdasarkan pengamatan yang dilakukan melalui studi pustaka, kami menemukan bahwa praktek pelaksanaan nikah sirri di Kabupaten Probolinggo ini tergolong tinggi. Hal ini terjadi karena masyarakat tidak kurang memahami dampak hukum yang timbul dari perkawinan sirri. Oleh karena itu, diperlukan sebuah penyuluhan hokum sebagai media untuk mendidik masyarakat tentang akibat hukum perkawinan di bawah tangan (sirri). Pendekatan yang 
diterapkan dalam pengabdian ini adalah pendekatan kualitatif, dengan cara menanyakan langsung kepada warga.

Pengabdian ini dilakukan sejak pengajuan judul pada tanggal 13 Juni 2021 dan mulai menentukan lokasi serta bentuk kegiatan sampai dengan tanggal 01 September 2021. Mengawali kegiatan, tim pengabdian membawa surat tugas KKN dari kampus untuk disampaikan kepada Pengasuh Pondok Pesantren Al-Mashduqiah sebagai koordinasi awal. Dukungan dari Pengasuh Pondok Pesantren Al-Mashduqiah sangat dibutuhkan dalam kelancaran kegiatan pengabdian ini. Adapun tahapan pelaksanaan pengabdian ini dapat dilihat pada alur berikut:

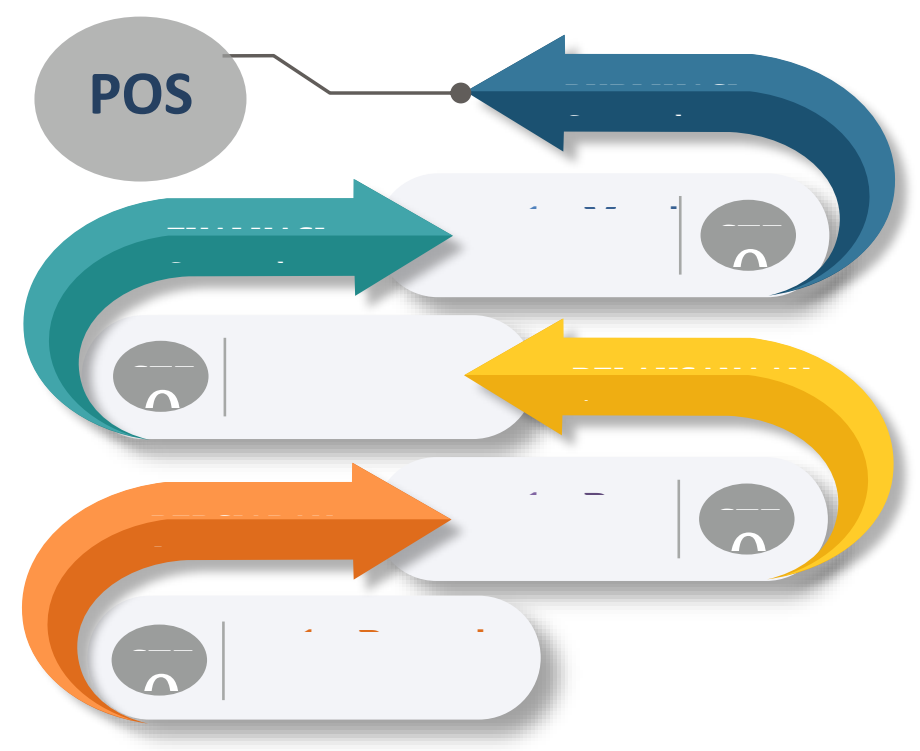

a. Tahap Persiapan

Tahap ini meliputi: identifikasi subyek dan obyek, penentuan lokasi, pengajuan judul, dan koordinasi dengan pihak terkait (Pengasuh dan Pengurus Pondok Pesantren Al-Mashduqiah).

b. Tahap Pelaksanaan

Tahap ini meliputi beberapa rangkaian kegiatan, antara lain:

- Perencanaan kegiatan, dengan cara melakukan koordinasi dan konsolidasi dengan seluruh tim dan relawan. Dalam tahap ini, tupoksi tiap seksi telah ditentukan secara rinci.

- Penyusunan bahan pemaparan yang akan dibagikan kepada peserta, berupa artikel, poster, dan slide power point. 
- Penyuluhan hukum ini dilakukan dengan konsep diskusi interaktif untuk memunculkan komunikasi dua arah antara penyuluh hukum dan peserta mengenai akibat hukum yang timbul dari perkawinan di bawah tangan (sirri). Adapun peserta penyuluhan hukum ini adalah santriwati senior Pondok Pesantren Al-Mashduqiah yang berusia di atas 17 tahun, pemilihan santriwati senior ini dikarenakan mereka dianggap sudah memasuki usia matang untuk melanjutkan ke jenjang pernikahan. Penyuluhan hukum ini bertujuan untuk memberikan pemahaman kepada peserta mengenai dampak negatif yang timbul bagi istri dan anak dari suatu perkawinan di bawah tangan (sirri).

c. Tahap Evaluasi

Waktu pengabdian ini dibatasai hingga akhir September 2021, oleh karenanya pada awal September 2021 tim pengabdian memutuskan untuk mulai masuk ke tahapan terakhir, yaitu mengevaluasi kegiatan. Sasaran dari kegiatan ini adalah santriwati senior di lingkungan Pondok Pesantren Al-Mashduqiah yang berusia di atas 17 tahun.

\section{Hasil dan Pembahasan}

\section{Persiapan Kegiatan}

Persiapan dilakukan beberapa hari sebelum hari pelaksanaan dengan dibantu oleh pihak pengurus Pondok Pesantren Al-Mashduqiah dan beberapa mahasiswa dari Program Studi Hukum Universitas Nurul Jadid Paiton Probolinggo yang tergabung dalam tim pengabdian. Persiapan yang dilakukan, antara lain penggandaan soal Pre Test dan Post Test, Materi Penyuluhan, Poster/Flyer, beserta alat tulis yang diperlukan. Tepat satu hari sebelum waktu pelaksanaan, dilakukan pemasangan spanduk, backdrop, sound system (microphone dan speaker), pemasangan infokus dan layar infokus, dan/atau menata letak isi ruangan dengan alat perlengkapan. Kemudian mempersiapkan plakat yang akan diberikan pada saat pembukaan kegiatan berlangsung, dan mempersiapkan konsumsi yang akan diberikan kepada peserta. Peserta kegiatan penyuluhan hukum ini adalah santriwati senior Pondok Pesantren Al-Mashduqiah dengan rentang usia 17-20 tahun, pemilihan peserta dengan kriteria usia tertentu dikarenakan pertimbangan bahwa dalam waktu dekat mereka akan melaksanakan perkawinan. Tidak ada kendala yang berarti dalam persiapan kegiatan pengabdian ini. 


\section{Pelaksanaan Kegiatan}

Kegiatan Penyuluhan Akibat Hukum Perkawinan Di Bawah Tangan (Sirri) Bagi Santriwati Pondok Pesantren Al-Mashduqiah merupakan agenda yang dilakukan oleh Dosen Program Studi Hukum Universitas Nurul Jadid, yang mana dalam hal ini merupakan bagian dari program Pengabdian Kepada Masyarakat (PKM) LP3M Universitas Nurul Jadid. Alasan pemilihan lokasi kegiatan di Pondok Pesantren Al-Mashduqiah karena mayoritas masyarakat di lingkungan pesantrenlah yang banyak melakukan praktik perkawinan di bawah tangan (sirri) dengan dalih bahwa itu sah menurut syariat Islam.

Rangkaian kegiatan pengabdian dilakukan selama satu hari yang dimulai pada pukul 08.00 WIB hingga pukul 14.00 WIB, yakni pada tanggal 19 Agustus 2021. Pelaksanaan kegiatan diawali dengan proses registrasi peserta pada pukul 08.00 WIB. Peserta yang melakukan registrasi berjumlah 60 santriwati. Setelah registrasi dilakukan, seluruh peserta masuk ke dalam ruangan kemudian dilanjutkan dengan pembukaan kegiatan yang bertempat di Aula Graha Ihsana Kraksaan.

Pembukaan kegiatan berlangsung khidmat dan dibuka oleh Pembawa Acara (Mahasiswa Program Studi Hukum Universitas Nurul Jadid) yang diawali dengan menyanyikan lagu Indonesia Raya. Kemudian acara dibuka dengan kata sambutan oleh Pengasuh Pondok Pesantren Al-Mashduqiah yang didampingi oleh Pengurus Pondok, dilanjutkan dengan kata sambutan oleh Kepala Program Studi Hukum Universitas Nurul Jadid. Pada pembukaan kegiatan, disampaikan mengenai beberapa hal yaitu memperkenalkan Program Studi Hukum pada Fakultas Sosial den Humaniora Universitas Nurul Jadid beserta keunggulannya kepada peserta yang notabene siswa/i yang nantinya diharapkan akan melanjutkan pendidikan ke jenjang perguruan tinggi. Disampaikan pula tentang tujuan kegiatan yang dilakukan, manfaat, dan ulasan singkat tentang konsekuensi hukum yang timbul dari perkawinan di bawah tangan (sirri).

Penyuluhan kemudian dilanjutkan dengan sesi diskusi interaktif antara narasumber dan peserta terkait konsekuensi hukum yang timbul dari perkawinan di bawah tangan (sirri). Kegiatan ditutup dengan penyerahan Plakat oleh Narasumber/ Penyuluh kepada Pengasuh Pondok Pesantren AlMashduqiah secara simbolis yang dilanjutkan dengan sesi foto bersama. 

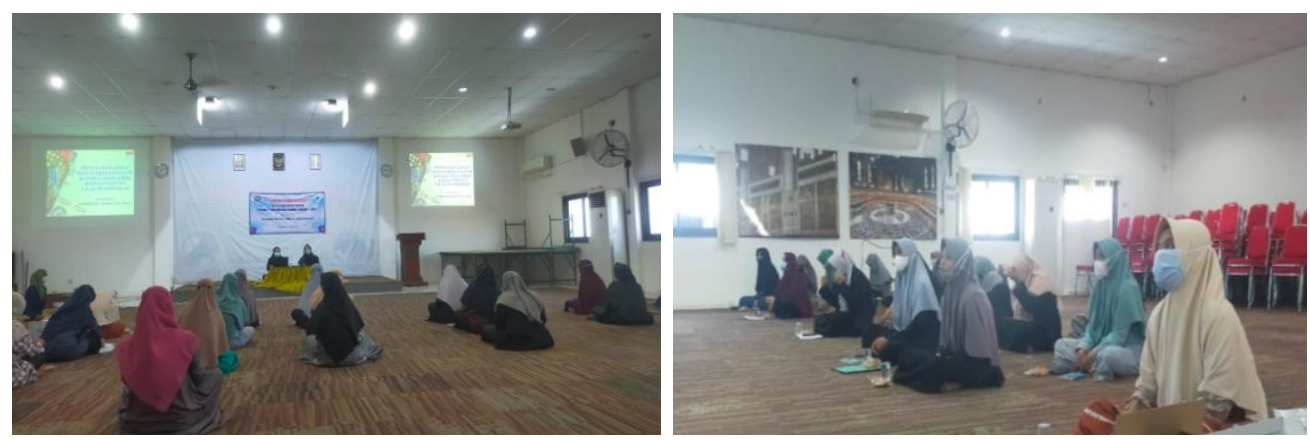

Gambar 1 menunjukkan pelaksanaan penyuluhan akibat hukum perkawinan di bawah tangan (sirri) yang diikuti oleh santriwati senior Pondok Pesantren AlMashduqiah.
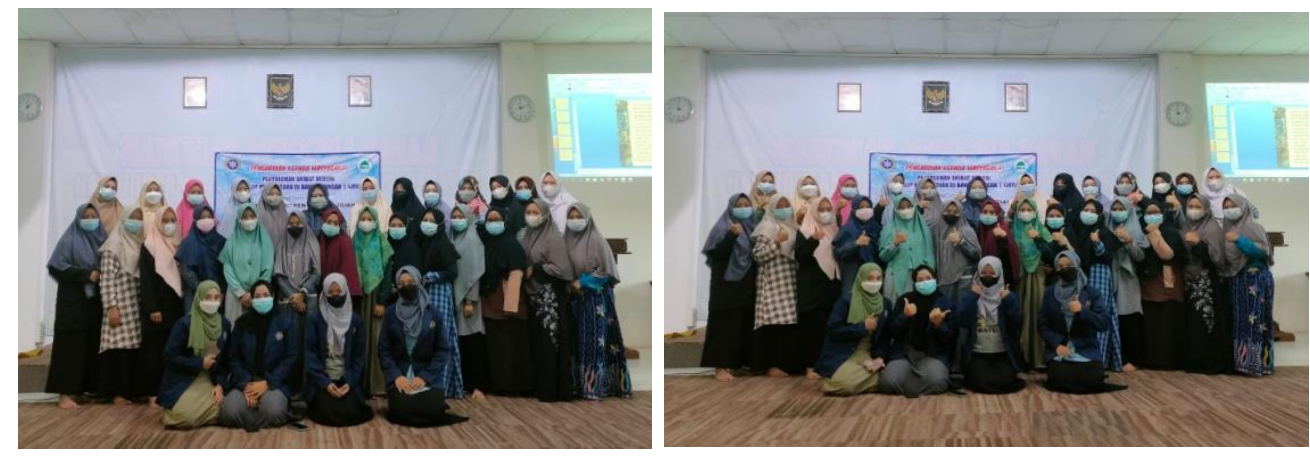

Gambar 2 menunjukkan prosesi foto bersama tim pengabdian bersama seluruh peserta.

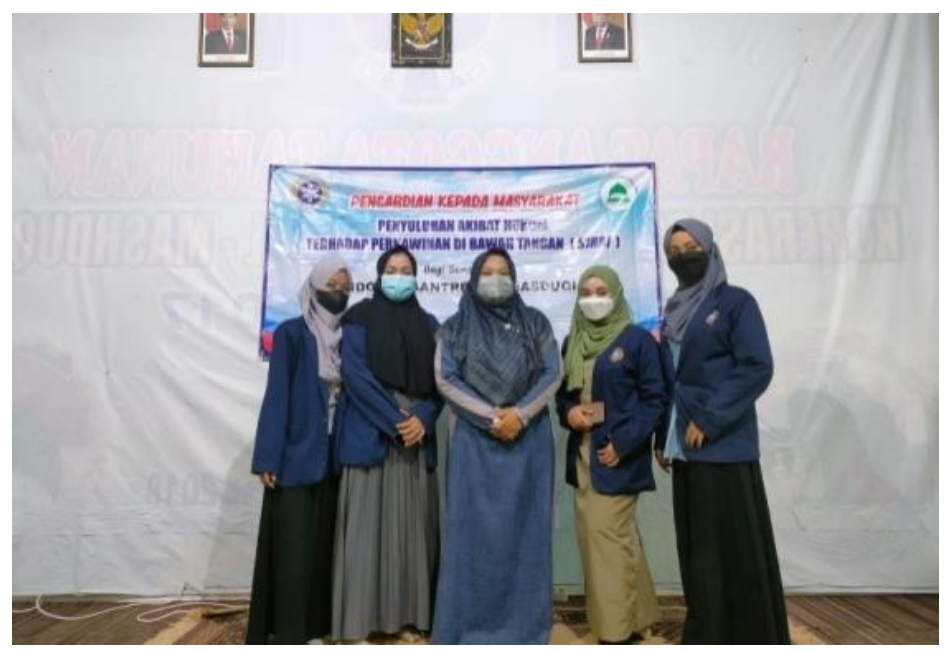

Gambar 3 menunjukkan prosesi foto bersama tim pengabdian. 


\section{Kesimpulan}

Berdasarkan kegiatan yang dilakukan di Pondok Pesantren AlMashduqiah, dapat disimpulkan bahwa upaya memberikan pemahaman kepada masyarakat mengenai dampak negatif yang timbul bagi istri dan anak dari suatu perkawinan di bawah tangan (sirri) merupakan tanggung jawab bersama. Upaya ini harus terus dilakukan secara kontinue untuk menyelamatkan hak anak yang dilahirkan dari suatu perkawinan di bawah tangan (sirri). Tingginya angka pernikahan anak di Kabupaten Probolinggo juga menyebabkan praktik pernikahan sirri semakin banyak terjadi, hal ini disebabkan oleh larangan penikahan bagi anak, sehingga masyarakat memilih menikah secara sirri tanpa memikirkan dampak negatif yang akan timbul di kemudian hari. Penyuluhan hokum yang telah dilakukan ini diharapkan dapat menambah pemahaman masyarakat Kabupaten Probolinggo pada umumnya, dan santriwati Pondok Pesantren Al-Mashduqiah pada khususnya, terkait akibat hukum yang timbul dari perkawinan di bawah tangan (sirri). Dalam hal ini, diperlukan keterlibatan pemimpin atau tokoh masyarakat setempat untuk ikut serta meningkatkan kesadaran masyarakat mengenai dampak negatif yang timbul bagi istri dan anak dari suatu perkawinan di bawah tangan (sirri).

\section{Pengakuan}

Syukur Alhamdulillah atas terlaksananya kegiatan pengabdian dengan tema Penyuluhan Akibat Hukum Perkawinan Di Bawah Tangan (Sirri) Bagi Santriwati Pondok Pesantren Al-Mashduqiah. Tim pengabdian mengucapkan banyak terima kasih kepada Bapak Pengasuh Pondok Pesantren AlMashduqiah beserta jajaran pengurusnya yang telah memberi ijin dan membantu terlaksananya kegiatan pengabdian hingga berjalan lancar dan sesuai dengan rencana. Semoga pengabdian kali ini bermanfaat bagi semua peserta yang mengikutinya. Tim pengabdian juga mengucapkan terimakasih banyak kepada Lembaga Pengembangan Pembelajaran dan Penjaminan Mutu (LP3M) Universitas Nurul Jadid yang telah memberikan kesempatan dan amanah kepada tim kami untuk melaksanakan kegiatan pengabdian, sehingga kami bisa mendapatkan pengalaman yang sangat berharga. 


\section{Referensi}

\section{Buku}

Soekanto, Soerjono \& Mamudji, Sri. (2001). Penelitian Hukum Normatif (Suatu Tinjauan Singkat). Jakarta: Rajawali Pers.

Hadikusuma, H. (2010). Hukum Perkawinan Indonesia menurut Perundangan, Hukum Adat, Hukum Agama. Bandung: Mandar Maju.

Haem, N. H. (2011). Awas Illegal Wedding, dari Penghulu Liar Hingga Perselingkuhan. Jakarta: Hikmah.

Hasan, M. A. (2013). Pedoman Hidup Rumah Tangga dalam Islam. Jakarta: Prenada Media.

Muthiah, A. (2017). Hukum Islam Dinamika Seputar Hukum Keluarga. Yogyakarta: Pustaka Baru Press.

\section{Peraturan Perundang-Undangan}

Kompilasi Hukum Islam.

Undang-undang Nomor 1 Tahun 1974 Tentang Perkawinan.

Undang-undang Nomor 23 Tahun 2002 Tentang Perlindungan Anak.

Peraturan Pemerintah Nomor 9 Tahun 1975 Tentang Pelaksanaan UndangUndang Nomor 1 Tahun 1974 Tentang Perkawinan.

\section{Jurnal}

Prihatin, F. (2009). Dampak Nikah Siri Terhadap Istri dan Anak. Jurnal Hukum Dan Pembangunan: Edisi Khusus Dies Natalis 85 Tahun FHUI, 148-157. 